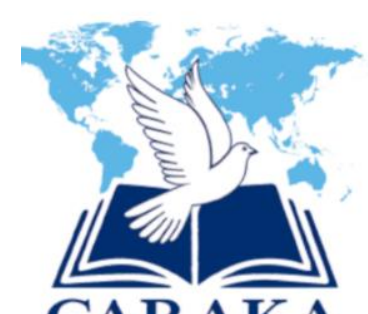

\title{
Perubahan-Perubahan Paradigma Dan Praksis Misi Gereja Di Era Society 5.0
}

\author{
Adrianus Pasasa, Yossua Hartaya \\ STT INTI Bandung \\ adrianuspasasa@gmail.com \\ yosuahartaya245@gmail.com
}

\begin{abstract}
Facing the massive changes that occur in society as a result of the Industrial Revolution 4.0 era, an era marked by a blend of technology that blurs the lines between the physical, digital, and biological fields. Between the physical and digital become connected. Acceleration towards the digital world was stimulated by the emergence of the Covid-19 pandemic. Changes in the Industrial Revolution 4.0 era will greatly impact the religious social life of mankind. The development of the Industrial Revolution 4.0 era, has given birth to changes in community culture which of course must also change the paradigm and praxis of the church's mission. The paradigm and praxis of the church's mission need to be evaluated and rethinking and reconstruction need to be carried out in the light of God's Word and contextually. This study uses the following methods: 1. Systematic Literature Review by collecting several references through literature study so as to obtain data related to the paradigm and praxis of the church's mission that is developing; 2. Hermeneutics by examining several Bible verses related to the topic as the basis for the construction of paradigms and missionary praxis in the era of the Industrial Revolution 4.0. The results of this study are expected to contribute to the church, especially with regard to the construction of the paradigm and practice of the church in carrying out its mission.
\end{abstract}

Keywords: Change; Paradigm; Praxis; Industry Society 5.0

\begin{abstract}
Abstrak
Menghadapi perubahan-perubahan secara masif yang terjadi di tengah-tengah masyarakat akibat era Revolusi Industri 4.0 yaitu sebuah era yang ditandai dengan perpaduan teknologi yang mengaburkan garis antara bidang fisik, digital, dan biologis. Antara yang fisik dan digital menjadi terkoneksi. Akselerasi menuju dunia digital distimulasi dengan munculnya pandemi Covid-19. Perubahan-perubahan pada era Revolusi Industri 4.0 akan sangat berdampak pada kehidupan sosial religius umat manusia. Perkembangan era Revolusi Industri 4.0, telah melahirkan perubahan-perubahan budaya masyarakat yang tentunya juga harus mengubah paradigma dan praksis misi gereja. Paradigma dan praksis misi gereja perlu dievaluasi dan perlu dilakukan rethinking dan recontsruction di dalam terang Firman Allah dan kontekstual. Penelitian ini menggunakan metode: 1. Systematic Literature Review dengan cara mengumpulkan beberapa rujukan melalui studi kepustakaan sehingga mendapatkan data-data berkaitan dengan paradigma dan praksis misi gereja yang sedang berkembang; 2 . Hermeneutika dengan cara menelaah beberapa ayat Alkitab yang berkaitan dengan topik
\end{abstract}


sebagai dasar bagi kontruksi paradigma dan praksis misi di era Revolusi Industri 4.0. Hasil dari penelitian ini diharapkan dapat memberikan sumbangan bagi gereja khususnya berkaitan dengan konstruksi paradigma dan praksis gereja dalam menjalankan misinya.

Kata Kunci: Perubahan; Paradigma; Praksis; Masyarakat Industry 5.0

\section{PENDAHULUAN}

Perubahan-perubahan masif yang sedang terjadi di tengah-tengah masyarakat saat ini, adalah dampak dari perkembangan ilmu pengetahun dan teknologi atau lebih dikenal dengan istilah era revolusi industry 4.0. Era industry 4.0 adalah sebuah era dimana ditandai dengan perpaduan teknologi serta meningkatnya konektivitas, interaksi serta perkembangan system digital, kecerdasan artifician, dan virtual yang mengaburkan garis antara bidang fisik, digital dan biologis. ${ }^{1}$ Kemajuan bidang teknologi dan informasi di era revolusi industry 4.0 berimbas pada berbagai sector kehidupan manusia, hal ini dapat dilihat melalui pengaruh-pengaruh yang ditimbulkan, seperti pertukaran informasi yang dapat dilakukan dengan mudah dan lebih cepat. Banyak pekerjaan yang dapat dilakukan dengan mudah, efisian dan efektif. Sistim pembelajaan dan transaksi dengan muda dilakukan secara online.

Perubahan-perubahan pada era Revolusi Industri 4.0 juga akan sangat berdampak pada kehidupan sosial religius umat manusia. Misalnya dengan adanya pandemic covid-19 yang tidak hanya berdampak pada kesehatan, tetapi dampaknya hampir kesemua sector kehidupan manusia. Pembatasan-pembatasan aktivitas dan pertemuan orang dalam waktu yang sama juga di batasi, himbauan untuk menghindari tempat-rempat keramaian dan larangan untuk melakukan perjalanan serta menunda perjalanan ke tempat lain. Demikian juga dengan tata cara bersosialisasi mengalami perubahan seperti tata cara bersalaman, berjabat tangan dan berpelukan. Semua kegiatan disarankan dilakukan dalam rumah dan dilakukan secara online. Hal ini juga berimbas pada berbagai oraganisasi keagamaan di berbagai belahan dunia, mereka mencari solusi baru untuk melakukan ibadah dan mereka mulai mengubah tata ibadah, salah satunya adalah ibadah dilakukan secara online. Kesediaan teknologi akan sangat membatu dalam berbagai hal, misalnya live streaming berbagai kegiatan, termasuk kegiatan keagamaan.

Perkembangan era Revolusi Industri 4.0, telah melahirkan perubahan-perubahan budaya masyarakat yang tentunya juga harus mengubah paradigma dan praksis misi gereja. Secara umum misi gereja adalah: Memberitakan Injil ke seluruh dunia dan menjadikan setiap bangsa murid Tuhan (Matius 28:19-20; Markus 16:15; Yohanes 14:12; Matius 18:11; Matius 4:19; 2 Kor 5:18), melayani sebagai komunitas yang memuji dan bersekutu bersama, dengan demikian mewujudkan kehadiran dan kasih Kristus (Wahyu 4:11; Yohanes 4:23; Markus 12:30-31), mendewasakan orang-orang percaya dan memersiapkan mereka untuk melakukan tugas pelayanan (Efesus 4:11-12), mewakili Kerajaan Allah di tengah-tengah dunia dan untuk memengaruhi masyarakat di sekitar kita dengan prinsip-prinsip ilahi (Matius 5:13-14). ${ }^{2}$ Misi gereja adalah misi yang yang berasal dan memancar dari hati Allah yang dinyatakan melalui penginjilan dan penjangkauan dengan satu tujuan membawa setiap orang kepada keselamatan melalui Yesus Kristus.

Dalam menjalankan misinya, gereja harus melepaskan dirinya dari paradigma dan praksis yang lama, dimana gereja jangan merasa nyaman dengan kurungan emas anugerah Allah, gereja jangan bersembunyi dalam pernyataan bahwa gereja hanya mengurus kehidupan

${ }^{1}$ D. Lase, "Pendidikan Di Era Revolusi Industri 4.0," Sunderman JCTES 1(1) (2019): 29.

2 "Apa Misi Gereja? | e-MISI," accessed June 26, 2021, https://misi.sabda.org/apa-misi-gereja.

295 | Copyright $\odot$ 2021, CARAKA, ISSN 2722-1407 (Cetak), 2722-1393 (Online) 
rohani saja. ${ }^{3}$ 'Tetapi gereja harus berperan aktif menyikapi dan memanfaatkan teknologi di era industry 4.0, sebagai tools dalam menjalankan misinya. Gereja harus mampu melihat potensi yang dimiliki oleh teknologi, akselarasi teknologi dalam pelayanan misi gereja adalah hal yang positif. Gereja harus memanfaatkan perkembangan teknologi di era industry 4.0, guna mempersiapkan diri memasuki era society 5.0, tanpa kesiapan gereja dalam menjalankan misinya akan lamban. Momen pandemik Covid-19 ini telah membuktikan bahwa proses perubahan itu sangat cepat dalam masyarakat. Kalau selama ini gereja dalam menjalankan misinya dengan cara berkunjung ke ladang misi dan bertemu dengan orang yang ada di sana secara face to face, tetapi dengan adanya pandemic covid-19 yang melanda dunia, metode seperti ini tidak mungkin lagi dilakukan. Karena akan memperlambat bahkan menghambat gereja dalam menjalankan misinya. Era Industri 4.0 memberi kesempatan yang sangat besar dan sangat terbuka bagi gereja dalam menjalankan misinya, dimana misi gereja dapat disampaikan kepada setiap orang di seluruh dunia secara real time kepada siapa saja, karena teknologi tidak mengenal batas wilayah, agama, suku dan ras. Era industry 4.0, menantang gereja untuk mengubah paradigma dan praksis dalam menjalankan misinya.

Agar lebih terarah penelitian ini, maka penulis memberikaan rumusan masalah yaitu sejauh mana gereja membangun paradigma dan praksis misinya dalam menghadapai ekses yang ditimbulkan oleh era society 5.0.?

\section{METODE PENELITIAN}

Penelitian ini menggunakan metode: 1. Systematic Literature Review dengan cara mengumpulkan beberapa rujukan melalui studi kepustakaan terhadap berbagai sumber literature berupa jurnal teologi ataupun buku-buku yang sesuai dengan tema, sehingga mendapatkan data-data yang berkaitan dengan paradigma dan praksis misi gereja yang sedang berkembang,; 2. Hermeneutika dengan cara menelaah beberapa ayat Alkitab yang berkaitan dengan topik sebagai dasar bagi kontruksi paradigma dan praksis misi di era Revolusi Industri 4.0 dan kesiapan menghadapi era Society 5.0. Selain itu juga menggunakan Alkitab sebagai referensi primer dan buku-buku serta sumber-sumber primer lain yang relevan dengan topik sesuai prinsip literatur review yang dimaksud oleh Denney ${ }^{4}$

Data yang diperoleh dari berbagai sumber literatur, jurnal teologi, maupun informasi dari media cetak dan elektronika yang relevan dengan topik yang dibahas, dikumpulkan, diseleksi dan dikelompokkan, kemudian diadakan pembahansan dan analisa.

\section{HASIL DAN PEMBAHASAN}

\section{Perubahan-Perubahan Kultur Era Siciety 5.0}

Era Society 5.0 tidak muncul begitu saja, tetapi sudah didahului oleh era-era sebelumnya. Era Society 1.0 pada era ini manusia masih berada pada era berburu dan mengenal tulisan. Era society 2.0, pada era ini manusia mulai mengenal bercocok tanam. Era society 3.0, pada era ini manusia mulai memasuki era industry, dimana manusia sudah mulai menggunakan mesin untuk membantu aktifitas mereka sehari-hari. Era society 4.0, pada era

${ }^{3}$ Fredy Siagian, "Pemandangan Rekonstruksi Misi Gereja Di Abad 21,” Jurnal Ilmiah Indonesia 1, no. 4

${ }^{4}$ Andrew S. Denney and Richard Tewksbury, "How to Write a Literature Review," Of Criminal Justice Education 24, no. 2 (2013): 221.

296 | Copyright $@$ 2021, CARAKA, ISSN 2722-1407 (Cetak), 2722-1393 (Online) 
ini manusia memasuki era teknologi, dimana manusia dimungkinkan untuk mengakses dan membagikan informasi melalui internet. Era society 5.0, pada era ini semua teknologi adalah bagian dari kehidupan manusia, internet tidak hanya sekedar media informasi, melainkan untuk menjalani kehidupan. Begitu juga dengan era revolusi industry yang di mulai dari era revolusi industry 1.0 pada abad ke-18, dimana pada era ini di temukan mesin uap. Revolusi industry 2.0 lahir pada abad ke-20 yang ditandai dengan ditemukannya listrik. Revolusi industry 3.0 ditandai dengan ditemukannya komputer dan robot. Era revolusi industry 4.0, ditandai dengan digabungkannya teknologi siber dan otomatisasi.

Kemajuan teknologi yang begitu pesat yang ditandai dengan revolusi industry 4.0, dimana revolusi industry 4.0 telah melahirkan bermacam-macam inovasi dalam dunia industry dan telah banyak mengubah kultur dalam masyarakat. Setelah era industry 4.0, kemudian dilanjutkan dengan era society 5.0 untuk menjawab tantangan-tantangan yang muncul akibat era industry 4.0.

Konsep society 5.0 sebenarnya sudah lama dicanangkan untuk merespon adanya dampak global akibat dari revolusi industry 4.0. Pada intinya konsep Society 5.0 adalah konsep masyarakat yang terpusat pada manusia (human centered) yang berbasis pada teknologi (technology based) yang digagas oleh Jepang sebagai kelanjutaan dari revolusi industry 4.0. Society 5.0 diresmikan tanggal 21 Januari 2019 dan dibuat sebagai solusi atas revolusi industri 4.0 yang ditakutkan akan mendegradasi umat manusia. Konsep Sosiety 5.0 dimaksudkan untuk mewujudkan masyarakat yang manusianya benar-benar menikmati hidup dan merasa nyaman. ${ }^{5}$

Era society 5.0 telah berdampak pada munculnya perubahan-perubahan kultur dalam masyarakat. Masyarakat di era society 5.0 dituntut untuk dapat menyelesaikan berbagai persoalan dan tantangan yang terjadi dalam masyarakat dengan memanfaatkan berbagai teknologi yang lahir di era industry 4.0, seperti Internet on Things, Artifician Intelligence (kecerdasan buatan), big data (data dalam jumlah besar), dan robot, semuanya dapat dimanfaatkan untuk meningkatkan kualitas hidup manusia. Jadi era industry 4.0 adalah era dimana Penggunaan ilmu pengetahuan berbasis modern (ai, robot, iot, dsb) untuk melayani kebutuhan manusia. Pada era society 5.0 akan terjadi perubahan-perubahan yang akan memunculkan suatu kearifan baru, dimana kecerdasan buatan (artificial intelligence) akan mentrasformasi big data yang dikumpulkan melalui internet dalam segala bidang kehidupan manusia (the Internet of Things). Hal ini dapat meningkatkan kemampuan manusiaa dalam membuka peluang-peluang baru bagi kemanusiaan serta membantu manusia dalam menjalani kehidupan yang lebih bermakna.

\section{Pengertian Misi}

Secara etimologis kata 'misi' berasal dari kata Latin missio yang artinya adalah perutusan. Kata missio merupakan kata benda dari kata kerja Latin mittere yang bisa berarti mengutus, mengirim, membuang, membiarkan. ${ }^{6}$ Misi adalah pertemuan antara gereja dengan agama-agama non Kristen, dengan kebudayaan yang jauh dari pengaruh Injil dan dengan

\footnotetext{
${ }^{5}$ Sumaryono, “Antara Revormasi Industri 4.0 \& Sosiality 5.0," accessed June 27, 2021, https://eprints.latbangdjogja.web.id/68/1/Berkreasi-Dalam-Solusi-Ugm.pdf.

${ }^{6}$ Raja Oloan Tumanggor, Misi Dalam Masyarakat Majemuk, ed. Tim GPL (Jakarta: Gentra Pustaka Lestari, 2014), 1-2.
} 
masyarakat yang belum mengenal Kristus. ${ }^{7}$ Pada abad ke-16 ada bermacam-macam istilah misi yang digunakan, diantaranya: propagatio fidei (penyebaran iman), convertio gentilium (pertobatan orang kafir), convertio infidelium (pertobatan orang tak percaya), propagatio regni Christi (penyebaran Kerajaan Kristus), dilatatio ecclesiae (perluasan gereja), plantator ecclesiae (penanam gereja). Sedangkan abad ke-17 istilah misi sudah umum dipakai di dalam gereja.

Misi Allah (Missio Dei) adalah bagian utama yang menjadi landasan sejarah keselamatan manusia. Allah adalah Allah yang missioner. Rencana Allah bagi dunia adalah membawa setiap orang dari suku dan bangsa, kaum dan bahasa berdiri di hadapan tahta Allah, menyembah anak domba untuk selama-lamanya (Wahyu 5:9). Setiap orang percaya ditantang untuk pergi melintasi batas-batas budaya untuk memberitakan Injil bagi setiap orang yang belum terjangkau dengan berita Injil. David Howard salah seorang pemimpin misi menjelaskan dasar alkitabiah dari pekabaran Injil sebagai berikut:

Kegiatan gereja untuk mengabarkan Injil bukanlah sebuah piramid yang dibangun terbalik dan bertumpuh pada satu ayat dalam kitab Perjanjian Baru yang terlepas dari ayat-ayat lain, lalu di atasnya kita membangun sebuah bangunan yang sangat besar yang dikenal sebagai "pengabaran injil". Kegiatan gereja untuk mengabarkan Injil merupakan sebuah pyramid besar yang dibangun tegak dengan ujungnya di atas dan dasarnya mulai dari kitab Kejadian pasal 1 sampai dengan kitab Wahyu pasal 22. Seluruh isi Alkitab membentuk dasar untuk pengabaran Injil ke seluruh dunia. ${ }^{8-}$

L. Legrand mengusulkan defenisi misi sebagai: 1) upaya mendekati orang kafir dan membawa mereka pada iman dan Allah yang benar (gerak sentrifugal), 2) upaya menjadikan diri/bangsa Israel sebagai poros, sehingga bangsa lain berkumpul di Yerusalem (proses eskatologis dengang gerak sentripetal), 3) peziarahan dari bangsa yg sudah ditebus menuju tanah terjanji. Israel sebagai bangsa terpilih yg dibebaskan dari perbudakan Mesir dan bergerak menuju tanah terjanji (Kel 13, 3.14). ${ }^{9}$

Paradigma misi saat ini menekankan bahwa Allah adalah pemilik Misi, Missio Dei (pengutusan dari Allah), yang menghendaki semua umat manusia diselamatkan, di mana gereja mendapat mandat untuk menjalankan misi. Tugas gereja diutus ke dalam dunia adalah persekutuan, pelayanan dan kesaksian, namun gereja sendiri bukanlah pemilik misi itu. ${ }^{10}$

\section{Paradigma dan Praksis Misi Dalam Perjanjian Lama}

Setelah manusia jatuh dalam dosa, misi Allah dimulai dengan memberi janji keselamatan kepada manusia yang telah jatuh dalam dosa (Kejadian 3:15). Janji keselamatan itu adalah inisiatif Allah untuk menyelamatkan manusia yang telah jatuh dalam dosa, dan keselamatan itu semata-mata karunia Allah. Selanjutnya Allah memanggil Abraham, pemanggilan dan pengutusan Abraham merupakan era baru dalam misi penyelamatan Allah. Panggilan dan pengutusan Allah kepada Abraham dapat dikatakan sebagai misi pertama dalam Perjanjian Lama. Abraham diutus Allah untuk menjadi berkat bagi semua kaum di muka bumi

${ }^{7}$ Raja Oloan Tumanggor, Misi Dalam Masyarakat Majemuk.

${ }^{8}$ Adrianus Pasasa, "Misi Penginjilan," accessed June 28, 2021, http://a31-misipenginjilan.blogspot.com /2012/02/dasar-alkitab-tentang-misi-dalam.html,.

${ }^{9}$ Raja Oloan Tumanggor, Misi Dalam Masyarakat Majemuk, 14.

${ }^{10}$ Fernando Tambunan, "Tantangan Misi Dalam Prespektif Pemikiran Era Postmodern Related Papers," n.d., 2. 
(Kejadian 12:1-3). Abraham telah memberi teladan kepada keluarga dan anak-anaknya, ketaatannya telah diwarisi oleh anak-anaknya.

Selanjutnya Allah memilih dan mengutus Musa untuk membebaskan umat-Nya dari perbudakan di tanah Mesir. Karena kasih-Nya kepada umat-Nya, Allah membebaskan mereka dari perbudakan di Mesir dan membawa mereka mewati padang gurun menuju tanah perjanjian yaitu tanah Kanaan yang subur dan berlimpah susu dan madu. Tujuan Allah memilih Israel adalah supaya Israel dapat melakukan misi Allah di tengah-tengah bangsa lain. Pemilihan Israel semata-mata karena kasih Allah kepada mereka (Kel 19:5-6), Israel adalah alat yang akan digunakan untuk menjalankan misi Allah untuk menyelamatkan bangsa-bangsa. Melalui Israel nama Tuhan akan dimuliakan dan ditinggikan di tengah bangsa-bangsa.

Tahap selanjutnya Allah memilih dan mengutus orang-orang tertentu untuk dipakai dan diutus sebagai pemeran dalam rencana penyelamatan manusia yang sedang dikerjakan Allah. Mereka diutus untuk menyatakan kebenaran dan keselamatan dari Allah. Allah juga memanggil dan mengutus para Nabi untuk menyatakan kehendak-Nya yaitu pemberitaan tentang penghukuman dan janji keselamatan, dimana mereka diutus dalam situasi dan keadaan yang berbeda-beda. ${ }^{11}$ Misalnya Allah mengutus nabi Yunus pergi ke Ninewe. Alkitab mencatat kota Ninewe dikenal dengan keindahannya, kekuatan militernya, namun sekaligus kota yang penuh penindasan, kekerasan dan ketidakadilan. Alkitab mencatat bahwa kejahatan kota Ninewe menjadi masalah utama, sehingga Allah mengutus nabi Yunus untuk menyerukan berita pertobatan (Yunus 1:2; 3:2) supaya penduduk kota Ninewe bertobat dan berbalik kembali kepada Allah. Pengutusan nabi Yunus salah satu model pengutusan misa Allah dalam Perjanjian Lama dan sekaligus menjadi embrio misa dalam Perjanjian Baru. William Dyrness dalam pengamatannya berpendapat: "Perjanjian Lama mempersiapkan sebuah berita universal yang dalam Perjanjian Baru akan menjadi misi universal. ${ }^{12}$ Misi dalam Perjanjian Lama adalah Misi Allah untuk menyelamatkan manusia berdasarkan janji Allah tentang keselamatan bagi bangsa Israel.

\section{Paradigma dan Praksis Misi Dalam Perjanjian Baru}

Berbeda dengan misi perjanjian lama dimana Israel menjadi pusat dan bangsa-bangsa yang datang ke pada Israel. Tetapi misi dalam Perjanjian Baru dimulai dari pusat keluar (bersifat sentrifugal), artinya kabar keselamatan di mulai dari gereja atau dari Israel dan akan disampaikan kepada semua suku-suku bangsa.

Misi dalam Perjanjian Baru adalah bagian yang tak terpisahkan dari orang percaya dan merupakan tugas dan tanggung jawab setiap orang percaya. Hal ini dapat dilihat di dalam Injil Matius 28:18-20 yang lebih sering dikenal dengan sebutan "Amanat Agung", yang isinya adalah "Yesus mendekati mereka, dan berkata, "Seluruh kuasa di surga dan di bumi sudah diserahkan kepada-Ku. Sebab itu pergilah kepada segala bangsa di seluruh dunia, jadikanlah mereka pengikut-pengikut-Ku. Baptislah mereka dengan menyebut nama Bapa, dan Anak dan Roh Kudus", ajarlah mereka menaati semua yang sudah kuperintahkan kepadamu. Dan ingatlah Aku akan selalu menyertai kalian sampai akhir zaman." Setiap orang percaya harus menyadari bahwa misi pemberitaan Injil adalah tugas utama yang dipercayakan Tuhan kepada

${ }^{11}$ Megawati Manulang, “Misi Dalam Perjanjian Lama,” Jurnal Teologi “Cultivation” 3, no. 1 (2019): 80.

\footnotetext{
${ }^{12}$ Adrianus Pasasa, "Pemanfaatan Media Internet Sebagai Media Pemberitaan Injil,” Jurnal Simpson II
} (2015): 72.

299 | Copyright $@$ 2021, CARAKA, ISSN 2722-1407 (Cetak), 2722-1393 (Online) 
gereja, dan setiap orang percaya harus berperan dalam menjalankan Amanat Agung Tuhan Yesus.

Amanat Agung Tuhan Yesusakan terus berkesinambungan untuk misi gereja. Tuhan Yesus memberikan mandat/amanat/perintah kepada para murid-Nya untuk mengabarkan Injil. Mandat itu berupa empat kata kerja present tense yaitu "Pergi ( $\pi \circ \rho \varepsilon v \theta \varepsilon ́ v \tau \varepsilon \varsigma)$, Jadikan Murid ( $\mu \alpha \theta \eta \tau \varepsilon v ́ \sigma \alpha \tau \varepsilon)$, Baptislah ( $\beta \alpha \pi \tau i \zeta o v \tau \varepsilon \varsigma$ ) (ayat 19) dan sebuah kata kerja present tense pada ayat ke-20, yaitu Mengajarkan ( $\delta \imath \delta \alpha ́ \sigma \kappa o v \tau \varepsilon \varsigma)$. Nainggolan dalam tulisannya menguraikan kata pergi sebagai berikut:

Dalam bahasa Yunani, poreuthentes dapat dimengerti sebagai go (pergi), proceed (lanjutkan), dan travel (melakukan perjalanan). Dari tiga arti ini, dapat disimpulkan bahwa pelaksanaan Amanat Agung harus dilakukan dalam setiap situasi, di mana saja kita berada (sementara kamu pergi....), di komunitas hidup sehari-hari (melanjutkan....), dan terlibat dengan proyek misi, baik sebagai misionaris atau sebagai pengutus (melakukan perjalanan.....). Penjelasan kedua arti kata poreuthentes dalam Bible Works 8 adalah sebagai berikut: "as a euphemism go to one's death". Penjelasan ini mempunyai arti setiap murid dipanggil untuk menjadi radikal dalam arti taat sampai mati seperti Kristus sendiri. ${ }^{13}$

Penulis Perjanjian Baru mengajak setiap orang percaya supaya menjalankan Amanat Agung. Sejak hari Pentakosta, proses amanat Agung sudah mulai dijalankan (Kisah Para Rasul 2). Para murid Tuhan Yesus yang dipenuhi dengan Roh Kudus, hatinya berkobar-kobar untuk memberitakan Injil kepada orang-orang berdosa (Kisah Para Rasul 2:1-4). Sejak peristiwa Pentakosta gereja mulai mengerjakan misi kepada dunia melalui para murid yang tersebar dari Yerusalem, Yudea, Samaria dan sampai ke ujung bumi (Kisah Para Rasul 1:8). Penganiayaan terhadap orang-orang percaya di Yerusalem membawa mereka keluar dari Yerusalem untuk menjangkau wilayah-wilayah di luar Yerusalem (Samaria, Antiokia, Siprus, Fenesia). Filipus pergi ke Samaria (Kis. 8:4-5), Barnabas ke Antiokia (Kis. 11:22-23), walaupun jangkauan mereka masih sebatas orang Yahudi yang berdiaspora ke wilayah-wilayah tersebut (Kisah Para Rasul 11:9). Di dalam Kis. 11:20-21, dikisahkan bahwa orang Kirene dan Siprus-lah yang memberitakan Injil kepada orang non-Yahudi, yaitu orang Yunani.

Misi gereja tidak dapat dipisahkan dari perintah Amanat Agung Tuhan Yesus Kristus. tujuan utama gereja adalah menjalankan Amanat Agung, sebab dengan menjalankan amanat agung berarti meneruskan misi Tuhan Yesus secara berkesinambungan.

Dalam Alkitab baik Perjanjian Lama maupun Perjanjian Baru memandang bahwa misi adalah karya Allah yang mengutus dirinya ke dalam dunia. Allah sangat serius dan konsisten dengan misinya untuk menyelamatkan manusia yang telah jatuh dalam dosa. Hal ini dapat dilihat dalam seluruh Alkitab, mulai dari kitab kejadian sampai wahyu semuanya terus menerus menyatakan kasih-Nya kepada manusia berdosa.

\section{Paradigma dan Praksis Misi Gereja menuju dunia digital}

Sejarah telah mencatat bahwa gereja dalam menjalankan misinya selalu menghadapi tantangan dan juga mengalami perkembangan yang signifikan dari waktu ke waktu. Perkembangan-perkembangan tersebut tidak hanya terjadi pada arsitektur, organisasi, doktrin, tetapi mencakup upaya gereja dalam memodernisasikan serta mengkontektualisasikan pelayanan di setiap waktu atau zaman yang berbeda.

${ }^{13}$ Nainggolan, B. D. (2014). Konsep Amanat Agung Berdasarkan Matius 28: 1820 Dalam Misi. Jurnal Koinonia, 6(2), 15-45.

300 | Copyright $\odot$ 2021, CARAKA, ISSN 2722-1407 (Cetak), 2722-1393 (Online) 
Kemunculan pandemi Covid-19 telah menstimulus munculnya paradigma-paradigma baru bagi gereja di dalam menjalankan misinya. Misi gereja tentu tidak harus berhenti hanya karena masalah Covid-19 ini, walaupun gereja dituntut untuk mengikuti peraturan pemerintah untuk tetap menaati dan menjalankan protokol Kesehatan, namun hal ini tidak akan menghentikan praksis misi gereja yang selama ini sudah dilakukan secara manual atau fisik. Dalam hal ini gereja dituntut untuk menemukan cara-cara yang tepat untuk tetap mengoptimalkan misinya.

Ke depan gereja akan digiring kepada suatu model yang baru, yaitu gereja dalam menjalankan misinya yang akan serba digital. Fenomena ini menunjukkan bahwa praksis misi gereja yang sebelumnya dilakukan bersifat fisik akan perlahan digantikan dengan mobilitas yang bersifat virtual. Dimasa pandemi Covid-19 Gereja dalam menjalankan misinya dituntut untuk memanfaatkan berbagai jenis alat teknologi. Di era digitalisasi ini, dapat dikatakan bahwa hampir semua populasi di dunia ini telah dan akan menggunakan dan memanfaatkan teknologi informasi dan komunikasi yang berbasis di gital. ${ }^{14}$

Sugiharto dalam pemaparannya pada kuliah umum STT INTI Bandung: "Kultur Digital Dan Manusia Pada Era Sociaty 5.0”, memaparkan keuntungan dan kerugian dari era digital ini. Era digital akan membawa banyak keuntungan bagi kehidupan manusia, diantaranya: ${ }^{15}$

1. Kelemahan manusia dapat diatasi, dimana daya ingat dan kecerdasan manusia dapat ditingkatkan, berbagai penyakit dan penuaan dapat dicegah, mempercepat dan memperlancar komunikasi, membuat perjalanan lebih mudah, dan lain sebagainya.

2. Kemampuan manusia dapat ditingkatkan: persepsi kian menjangkau realitas tersembunyi, kita dapat mengalami makin banyak menungkinan tanpa batas, generasi masa depan dapat berkomunikasi dengan kita melalui hologram dan pikiran yang diunggah, komunikasi langsung antar pikiran dimungkinkan melalui brain-net, dan sebagainya.

3. Dunia akan semakin trasparan: kita dapat mengetahui segala peristiwa yang terjadi dibelahan bumi mana pun, ruang-waktu bukan lagi halangan.

4. "Sharing Culture" makin luas: media memungkinkan semua orang terhubung dan saling berbagi, empati kian luas, Kerjasama antar jejaring semakin meriap.

Demikian juga bahaya yang ditimbulkan antara lain:

1. Fakta, Hoax, dan Fiksi campur aduk: kita makin mudah tertipu berita; orang makin mudah menggugah apa pun asal sensasional namun tanpa tanggungjawab; segala kepentingan bisa menyembunyikan diri dengan dalih seolah semuanya produk algorithmic automation ("the machine did all that, not us"); celakanya kita biasanya baru sadar atas dampak buruk hanya setelah menjadi viral.

2. Kehidupan pribadi dilanggar: dari big-data, data-data pribadi kita makin mudah dimanipulasi, sementara siapa pelakunya tidak jelas, sebab semua saling terkait.

3. Dominasi kesibukan tanpa makna: Ketika segala hal makin mudah, energi dan waktu kita cenderung dihabiskan untuk hal-hal tak penting yang menyerbu gawai kita.

Terlepas dari keuntungan dan kerugian yang ditimbulkan, Era digital ini dapat menjadi arena bagi gereja untuk menantang dirinya dalam memetahkan ulang strategi misinya. Era

${ }^{14}$ Deflit Dujerslaim Lilo, "Misi Gereja 'Menjangkau Yang Tidak Terjangkau Di Era Dan Pasca Pandemi Covid-19,"' Jurnal Teologi Dan Misi 3, no. 2 (2020): 208-209.

${ }^{15}$ Ignasius B. Sugiharto, "Kurlur Digital Dan Manusia Pada Era Society 5.0." 
digital menuntut gereja untuk memiliki pemahaman yang luas bahwa gereja dalam bermisi tidak hanya sebatas mencari keanggotaan, tetapi era digital ini menantang gereja untuk memperluas cakrawala dalam menjalankan misinya. Media sosial tidak hanya berfungsi sebagai pfatform dalam pelayanan tetapi gereja juga hadir secara konsisten dalam ruang digital. Gereja dalam menjalankan misinya mencari yang terhilang tidak lagi harus dilakukan di dalam gereja, melainkan dapat dilakukan di setiap tempat dalam dengan ruang dan waktu yang tidak terbatas.

Pada sisi yang lain era digital juga telah mempertemukan banyak orang dengan berbagai macam kreativitas dalam membangun interaksi satu sama lain. gereja harus menyikapi secara proaktif, karena gereja dalam bermisi akan lebih efektif, efisian dan menglobal. Era digital ini menjadi peluang yang sangat bernilai strategis, karena praksis misi gereja dapat dilakukan secara luas dan mendunia serta dapat diakses dalam waktu yang tidak terbatas.

Pada era digital ini menuntut kecakapan gereja dalam menjalankan misinya. Gereja dalam menjalankan misinya harus punya kemampuan untuk memaknai setiap informasi: mampu memilih mana informasi yang penting dan mana informasi sampah. Gereja harus punya kemampuan dalam membangun visinya. Gereja mampu mencipta hal yang berguna bagi umat manusia. "you are what you create". Gereja dalam menjalankan misinya mampu bekerja sama dan harus punya keberanian menghadapi situasi baru serta menemukan harapan dalam menghadapi ketaktergantungan. ${ }^{16}$

Perkembangan teknologi dan informasi mengakibatkan teknis-empiris-akan semakin cepat kadarluarsa (termasuk isu rev. Industri 4.0 atau pun 5.0), maka yang perlu dilakukan gereja dalam menjalankan misinya di era digital ini adalah selalu meng-update skill dan selalu punya gairah untuk terus belajar dan mencari. Gereja harus semakin memperdalam pemahaman atas kompleksitas kehidupan. Di era digital ini, gereja tidak hanya sekedar melihat perkara data dan algoritma, namun perpaduan unik rasa, relasi, data, imajinasi, intuisi, pengalaman, konteks, kontradisksi diri, ketakutan, kerinduan, dll.

\section{Jembatan antara misi gereja dengan kultur era industry 4.0 dan society 5.0}

Menyikapi paradigma misi dari waktu ke waktu yang terus diperhadapkan pada perubahan-perubahan situasi dan kondisi, maka gereja dalam menjalankan misinya harus terus belajar menyesuaikan diri guna menjawab setiap tantangan zaman yang dihadapi. Jangan sampai ada kesenjangan antara misi gereja dengan kultur yang sedang dan akan terjadi ke depan pada industry 4.0 maupun era society 5.0.

Pada zaman Kolonial misi dilakukan dengan cara mengutus misionaris dari Barat ke Timur, dari Eropa dan Amerika Utara ke Asia, Afrika dan Amerika Latin. Namun hal yang perlu diperhatikan ditengah-tengah kemajuan teknologi adalah paradigma misi harus direform, misalnya dalam hal praksis yang dulu dilakukan dalam menjalankan misi harus di selaraskan atau disesuaikan dengan era yang sedang berjalan. Tetapi perlu diingat bahwa isi dan berita dari misi itu sendiri tidak boleh diubah, hanya toolsnya yang berubah. Tugas misi gereja adalah bagaimana mempertemukan agama-agama non-Kristen dengan gereja dalam zaman yang tidak lagi dibatasi oleh wilayah, suku, ras, agama dan budaya. Era industry 4.0 dan Era society 5.0 merupakan era dimana gereja punya kesempatan untuk menciptakan model-model baru dalam menjalankan misinya dengan memanfaatkan perkembangan teknologi, sehingga

\footnotetext{
${ }^{16}$ Ignasius B. Sugiharto.
} 
tantangan-tantangan yang dihadapi selama ini, khusunya dalam misi penginjilan dapat diminimalisir.

Paradigma-paradigma misi yang selama ini sudah berjalan, perlu ditinjau dan dievaluasi kembali. Sejalan dengan perkembangan teknologi di era industry 4.0, maka di dalam menjalankan misinya gereja sudah harus mulai berpikir kritis, inovatif, dan kreatif. Gereja harus mulai berpikir bagaimana mengintegrasikan ruang maya dengan ruang fisik menjadi satu, sehingga gereja akan mengalami kemudahan dalam menjalankan misinya. Pada era society 5.0 semua aktivitas dan pekerjaan manusia akan difokuskan pada Human-Centred yang berbasis pada teknologi. Era society 5.0 gereja akan menjadi pengendali teknologi dalam hal ini gereja dalam bermisi akan memanfaatkan berbagai kemajuan teknologi dimana gereja sebagai pegendalinya. Hal ini akan membuat gereja benar-benar menikmati dan merasa nyaman dalam bermisi. Gereja akan semakin kreatif semakin kreatif, efisiensi, inovatif dan determination dalam bermisi. Jika gereja dalam menjalankan misinya tidak mengikuti perkembangan teknologi, maka di era society 5.0 ini, gereja tidak akan mampu dan melewatkan kemajuan teknologi sebagai peluang untuk menciptakan metode-metode baru dalam menjalankan misinya.

Era society 5.0 di tengah-tengah pandemi covid-19 menjadi tantangan tersendiri bagi gereja dalam menjalankan misinya. Oleh karena itu gereja harus memunculkan berbagai strategi dan metode dalam menyikapi kondisi yang sedang terjadi saat ini. Menghadapi era society 5.0 dan pandemi covid-19 gereja perlu memberi dukungan kepada para penggerak misi dengan menyediakan platform untuk mendukung program misi supaya dapat dilakukan secara daring sejalan dengan tuntutan era industry 4.0. Gereja harus menyiapkan Sumber Daya Manusia yang berkualitas sehingga mampu melakukan inovasi-inovasi yang akan melahirkan berbagai kreasi yang memberikan kontribusi bagi keberhasilan misi geraja di era society 5.0. selain itu gereja juga harus mulai memikirkan pembangunan infrastruktur digital.

Gereja harus serius menyikapi perkembangan dan perubahan-perubahan yang akan terjadi pada era Society 5.0, karena pada era ini banyak didominasi oleh generasi milenial yang akan menjadi sasaran misi gereja ke depan. Gereja harus menyadari bahwa Generasi milenial adalah generasi internet minded dengan kepercayaan diri tinggi dan lebih terbaka pada perubahan-perubahan yang terjadi, ini adalah peluang dan kesempatan bagi gereja untuk menjangkau kaum milenial bagi Kristus. Gereja harus hadir bagi kaum milenial, supaya mereka tidak terhilang di tengah arus kemajuan teknologi yang tidak terbendung. Gereja harus menyampaikan Injil Kerajaan Allah kepada generasi milineal supaya mereka dapat mengenal Allah yang benar yang sanggup menyelamat mereka di masa kini dan masa yang akan datang. Tidak dapat dipungkiri bahwa generasi milenial adalah generasi yang memanfaatkan media sosial sebagai tempat mereka untuk berinteraksi. Gereja harus menyadari ini hal ini, komunitas milenial harus menjadi perhatian bagi misi gereja di era society 5.0.

Era digital menjadi tantangan sekaligus memberi tawaran kepada gereja dalam menjalankan misinya. Sudah waktunya gereja memiliki cara pandang baru dan memberikan manfaat baru bagi kemajuan misi. Fakta di lapangan, kini hampir semua individu memanfaatkan kemajuan teknologi yang secara tidak langsung sudah membentuk gaya hidup serta kebiasaan para pengguna teknologi itu. Pengaruh kemajuan teknologi internet yang begitu cepat, telah mempengaruhi cara orang dalam bersentuhan dengan agama. Gereja harus bijak dalam mengambil peran menjalankan misinya di era digital ini, teknologi hanyalah sumber daya yang dapat dimanfaatkan oleh gereja dalam menjalankan misinya. Tapi misi gereja sesungguhnya adalah menjadikan pemberitaan Firman sebagai pusat. Gereja harus 
menjadikan perkembangan teknologi informasi dalam menjawab berbagai tantangan di masa yang akan datang dalam menjalankan misinya, misalnya membuat aplikasi media untuk misi penginjilan, media social untuk misi penginjilan, dan lain sebagainya.

\section{KESIMPULAN}

Perubahan zaman akan terus terjadi, perkembangan teknologi dan informasi khususnya di era revolusi Industri 4.0 dan memasuki era society 5.0 telah membuka mata gereja dalam mengimplementasikan misi Amanat Agung Tuhan Yesus. Gereja harus berusaha menjawab tantangan terlebih di masa pandemi Covid-19 ini yang secara tidak langsung telah mengurangi bahkan menghentikan gereja dalam menjalankan misinya secara fisik. Belum lagi dengan pemberlakuan pembatasan sosial berskala besar (PSBB) dan Physical Distancing menuntut gereja untuk mencari terobosan-terobosan baru untuk tetap menjalankan panggilan misinya. Dengan adanya penutupan sementara kegiatan di gereja dan pelarangan aktivitas kerohanian yang bersifat fisik akan menggiring gereja untuk masuk dalam era yang baru, dimana pelayanan misi yang selama ini dilakukan secara fisik akan diganti dengan pelayanan misi yang dilakukan secara digital.

Era digital ini akan semakin memudahkan gereja dalam bermisi, dimana gereja dapat membagikan informasi berita Injil dengan mudah, misalnya gereja dapat menyalurkan berita Injil hanya melalui perangkat elektronik/handphone dan berita Injil dengan mudah diterima oleh banyak orang dalam waktu yang singkat. Jika dibandingkan dengan pola-pola lama, era digital lebih efisian dalam waktu, tenaga dan dana.

Era industry 4.0 dan Era society 5.0 mengharuskan gereja untuk kembali mengevaluasi diri serta mengubah paradigma dan praksis dalam menjalankan misinya. Sedapatnya gereja dalam menjalankan misinya berusaha mengkontektualisasikan dirinya dengan era yang sedang terjadi saat ini. Era society 4.0 adalah era Penggunaan ilmu pengetahuan berbasis modern dimana gereja dapat memanfaatkan berbagai teknologi untuk menjalankan misinya. Sedangkan era society 5.0 akan mewujudkan gereja yang benar-benar menikmati dan merasa nyaman dalam bermisi, karena gereja tidak dikendalikan teknologi, melainkan gereja mampu mengendalikan teknologi dalam menjalankan misinya. Gereja akan semakin kreatif dalam bermisi dan semakin kreatif dalam menyelesaikan setiap persoalannya di ladang misi, sehingga misi gereja ke depan akan semakin efisiensi, inovatif dan determination.

Rekomendasi untuk peneliti yang lain yaitu penelitian yang dilakukan dalam penelitian ini hanya mengungkap sebagian kecil permasalahan yang berhubungan dengan PerubahanPerubahan Paradigma Dan Praksis Misi Gereja Di Era Society 5.0. Dalam hal ini masih banyak praksis misi gereja di era society 5.0 yang belum diungkap dalam penelitian ini. Untuk itu disarankan kepada peneliti berikutnya yang berminat melakukan kajian atau penelitian lebih lanjut agar dilaksanakan dengan lebih baik. Diperlukan penelitian lanjutan tentang perancangan aplikasi sebagai salah satu penunjang praksis misi gereja di era socisty 5.0

\section{DAFTAR PUSTAKA}

Adrianus Pasasa. (n.d.). Misi Penginjilan.

Apa Misi Gereja? | e-MISI. (n.d.).

D. Lase. (2019). Pendidikan di Era Revolusi Industri 4.0. Sunderman, JCTES 1(1), 32-33.

Deflit Dujerslaim Lilo. (2020). Misi Gereja "Menjangkau yang tidak Terjangkau di Era dan 
Pasca Pandemi Covid-19.” Jurnal Teologi Dan Misi, 3(2), 208-209.

Fernando Tambunan. (n.d.). Tantangan Misi Dalam Prespektif Pemikiran Era Postmodern Related papers.

Fredy Siagian. (2016). Pemandangan Rekonstruksi Misi Gereja Di Abad 21. Jurnal Ilmiah Indonesia, 1(4), 2.

Ignasius B. Sugiharto. (2021). Kurlur Digital dan Manusia pada Era Society 5.0.

Megawati Manulang. (2019). Misi dalam Perjanjian Lama. Jurnal Teologi “Cultivation, ” 3(1), 80.

Pasasa, A. (2015). Pemanfaatan Media Internet Sebagai Media Pemberitaan Injil. Jurnal Simpson, II, 72.

Raja Oloan Tumanggor. (2014). Misi dalam Masyarakat Majemuk (Tim GPL (Ed.)). Gentra Pustaka Lestari.

Sumaryono. (n.d.). Antara Revormasi Industri 4.0 \& Sosiality 5.0.

Tewksbury, A. S. D. and R. (2013). How to Write a Literature Review. Of Criminal Justice Education, 24(2), 221. 